\title{
A protocol for high-quality genomic DNA extraction from legumes
}

\author{
I.O. Agbagwa ${ }^{1,2}$, S. Datta ${ }^{1}$, P.G. Patil ${ }^{1}$, P. Singh ${ }^{1}$ and N. Nadarajan ${ }^{1}$ \\ ${ }^{1}$ Crop Improvement Division, Indian Institute of Pulses Research, \\ Kanpur, India \\ ${ }^{2}$ Department of Plant Science and Biotechnology, Faculty of Science, \\ University of Port Harcourt, Port Harcourt, Nigeria \\ Corresponding author: I.O. Agbagwa \\ E-mail: ikechukwu.agbagwa@gmail.com / ikejiro2002@yahoo.co
}

Genet. Mol. Res. 11 (4): 4632-4639 (2012)

Received July 3, 2012

Accepted July 26, 2012

Published September 14, 2012

DOI http://dx.doi.org/10.4238/2012.September.14.1

\begin{abstract}
Current DNA extraction protocols, which require liquid nitrogen, lyophilization and considerable infrastructure in terms of instrumentation, often impede the application of biotechnological tools in less researched crops in laboratories in developing countries. We modified and optimized the existing CTAB method for plant genomic DNA extraction by avoiding liquid nitrogen usage and lyophilization. DNA was extracted directly from freshly harvested leaves ground in pre-heated CTAB buffer. Chloroform:isoamyl alcohol (24:1) and RNase treatments followed by single-purification step decontaminated the samples thereby paving way for selective extraction of DNA. High molecular weight DNA yield in the range of 328 to $4776 \mathrm{ng} / \mu \mathrm{L}$ with an average of $1459 \mathrm{ng} / \mu \mathrm{L}$ was obtained from 45 samples of cultivated and wild Cajanus species. With an absorbance ratio at 260 to $280 \mathrm{~nm}$, a range of 1.66 to 2.20 , and a mean of 1.85 , very low levels of protein and polysaccharide contamination were recorded. Forty samples can be extracted daily at a cost between 1.8 and US\$2.0 per plant sample. This modified method is suitable for most plants especially members of the Leguminosae. Apart from Cajanus, it has been extensively applied in DNA extraction from Cicer and Vigna species.
\end{abstract}

Key words: DNA extraction; Leguminosae; RAPD; SSR; SRAP 


\section{INTRODUCTION}

The availability of pure uncontaminated genomic DNA is the key to success for most molecular biology experiments. Thus, the extraction of good DNA from plant materials is sine qua non for molecular studies in plant science and agricultural biotechnology. To underscore the importance of good quality and quantity of genomic DNA extraction for plant molecular studies, researchers continuously inundate the discipline with new DNA extraction procedures and modifications of existing protocols. These include but are not limited to Zhang and Stewart (2000), Karakousis and Langridge (2003), Xu et al. (2005), Manen et al. (2005), Bokszczanin and Przybyla (2006), Chakraborti et al. (2006), Chandra and Saxena (2007), Dehestani and Kazemi-Tabar (2007), Arbi et al. (2009), Sahasrabudhe and Deodhar (2010), Attitalia (2011), Biswas and Biswas (2011), Gupta et al. (2011), Gurudeeban et al. (2011), Japelaghi et al. (2011), Okpodu and Abdullah-Israel (2011), Sharma et al. (2012), and Tiwari et al. (2012). In one way or another, these authors agree that a good genomic DNA extraction procedure should be fast, inexpensive and simple (not laborious and hazardous), producing a good quantity of intact DNA of reasonable purity using small amounts of tissue and extraction chemicals. In other words, the absence of good-quality DNA is a major limiting factor to the success of polymerase chain reaction (PCR)-based downstream applications such as random amplified polymorphic DNA (RAPD), simple sequence repeats (SSR), sequence-related amplified polymorphism (SRAP), and amplified fragment length polymorphism (AFLP). Even with the flurry of information on this subject matter as aforementioned, DNA extraction from plant tissues, unlike DNA isolation from mammalian tissues, remains difficult due to the presence of a rigid cell wall surrounding the plant cells and differences in cell chemistry among and between species.

The most utilized DNA extraction procedure, the cetyltrimethylammonium bromide (CTAB) method (Doyle and Doyle, 1987), and majority of its published modifications apply liquid nitrogen, lyophilization (freeze-drying) or alternating cold (about $-80^{\circ} \mathrm{C}$ ) and heat shock $\left(60^{\circ} \mathrm{C}\right)$ for grinding and or rupturing the cell and nuclear walls. The procurement, storage and use of liquid nitrogen is cumbersome and hazardous while lyophilization or maintaining alternating temperatures $\left(-80^{\circ}\right.$ to $\left.60^{\circ} \mathrm{C}\right)$ is not continuously possible in most developing countries due to epileptic power supply. Automated enzymatic methods with accompanying commercial kits offered by such companies as Qiagen, Promega Corporation and Nucleopore, as well as automatic volume-dispensing units for DNA extraction, are expensive; their costs impede research in third world/developing countries. This also applies to the use of such high-throughput instruments such as the GenoGrinder. Therefore, a DNA extraction procedure, which successfully circumvents all these perceived challenges, is needed in developing countries, especially in Africa and Asia.

We report here a modified CTAB procedure for rapid plant DNA extraction suitable for developing countries in Africa and Asia. Liquid nitrogen, lyophilization or alternating cold and heat shock are not required to execute this procedure. The method utilizes 1.5- and 2-mL tubes instead of tubes of a $5-\mathrm{mL}$ volume and larger. Orbital shaking is replaced by manual rocking. The effectiveness of this procedure has been validated by subjecting the resultant genomic DNA samples to successful series of PCR for RAPD, SSR, SRAP, and AFLP studies in the Biotechnology Laboratory, Indian Institute of Pulses Research, Kanpur India.

\section{MATERIAL AND METHODS}

Genomic DNA was isolated from emerging young seedlings of Cajanus, Cicer and Vigna 
(data not shown for Cicer and Vigna) sown in the greenhouse of the Indian Institute of Pulses Research, Kanpur, India. Seedlings were harvested approximately 1 month after sowing.

\section{Reagents, chemicals and laboratory materials}

CTAB extraction buffer consisted of 3\% CTAB, $4 \mathrm{M} \mathrm{NaCl}, 20 \mathrm{mM}$ EDTA, and 100 $\mathrm{mM}$ Tris-HCl. Stock solutions of the different CTAB extraction buffer components were prepared following standard procedures. Other reagents and materials were $2 \% \beta$-mercaptoethanol, chloroform:isoamyl alcohol (24:1), phenol:chloroform:isoamyl alcohol (25:24:1), 100\% isopropanol, ethanol (absolute), sodium acetate (not compulsory), $10 \mathrm{mg} / \mathrm{mL}$ RNase and Tris-EDTA $\left(\mathrm{T}_{10} \mathrm{E}_{1}\right)$ buffer. Laboratory pestle and mortar, 1.5 - and 2-mL microcentrifuge tubes, micropipettes, microtips, pair of scissors, and a 40-well holding rack completed the materials. Centrifugation was carried out at different speeds (rpm) using Sigma 1-K, R. Code. 12132 centrifuge.

\section{Harvesting and grinding of plant material}

Fresh emerging leaves were harvested and wrapped in foil papers. These were immediately taken to the laboratory and kept in the refrigerator at $-20^{\circ} \mathrm{C}$ to retain freshness of the materials (i.e., where more than 20 samples were collected for extraction). The leaves were vigorously rinsed in distilled water to remove particles on leaf surfaces. About $200 \mathrm{mg}$ of each sample was gently ground into paste in a mortar with $2 \mathrm{~mL}$ CTAB extraction buffer (preheated at $65^{\circ} \mathrm{C}$ for at least $10 \mathrm{~min}$ ). To facilitate and speed up grinding, leaves were chopped into smaller bits with scissors. As a precaution, scissors were dipped in absolute ethanol before reuse. After grinding, equal volume (approximately $1 \mathrm{~mL}$ each) of the resultant paste was distributed into two separate $2-\mathrm{mL}$ microcentrifuge tubes. This stage took 3 to $5 \mathrm{~min}$ per sample.

\section{Extraction and purification protocol}

A volume of $2 \mu \mathrm{L} \beta$-mercaptoethanol was added to each tube, which was then mixed thoroughly by gently rocking the rack. Samples were incubated in a water bath at $65^{\circ} \mathrm{C}$ for at least $30 \mathrm{~min}(1 \mathrm{~h}$ is preferable). Samples were retrieved from the water bath after incubation and allowed to return to room temperature for 5 to $10 \mathrm{~min}$. An equal volume of chloroform:isoamyl alcohol (24:1) (i.e., $1 \mathrm{~mL}$ into each tube) was added for extraction. This was mixed gently by continuously rocking and inverting the tubes for up to $5 \mathrm{~min}$. Samples were centrifuged at 10,000 rpm for $15 \mathrm{~min}$ at $22^{\circ} \mathrm{C}$ to separate the phases. The top light green-colored aqueous phase was transferred to new $1.5-\mathrm{mL}$ microcentrifuge tubes, along with 0.75 volume chilled isopropanol (e.g., for $1 \mathrm{~mL}$ aqueous phase, $750 \mu \mathrm{L}$ chilled isopropanol added) to precipitate the DNA. Samples were mixed gently by continuous inversion, kept at $-20^{\circ} \mathrm{C}$ overnight or $-80^{\circ} \mathrm{C}$ (if available) for about $30 \mathrm{~min}$ followed by centrifugation to recover the DNA pellets.

The samples were centrifuged at $6000 \mathrm{rpm}$ for $8 \mathrm{~min}$ at $4^{\circ} \mathrm{C}$. Carefully, the supernatant was discarded being mindful of the DNA pellet; the pellets were washed in $70 \%$ ethanol and air-dried until ethanol evaporated completely from the samples. This was facilitated by inverting tubes on tissue paper or paper towel or using a vacuum blower. The DNA pellets were rehydrated/dissolved in $200 \mu \mathrm{L} \mathrm{T}{ }_{10} \mathrm{E}_{1}$ buffer and treated with $3 \mu \mathrm{L}$ RNase $(10 \mathrm{mg} / \mathrm{mL})$. Samples were incubated for 15 to $20 \mathrm{~min}$ at $37^{\circ} \mathrm{C}$. For purification, $200 \mu \mathrm{L}$ phenol:chloroform:isoamyl alcohol (25:24:1) was 
added followed by centrifugation for $10 \mathrm{~min}$ at $6000 \mathrm{rpm}$. The top layer was carefully pipetted into new $1.5-\mathrm{mL}$ microcentrifuge tubes, with the addition of an equal volume of chloroform:isoamyl alcohol (24:1) and centrifugation at $5000 \mathrm{rpm}$ for $5 \mathrm{~min}$ at $22^{\circ} \mathrm{C}$. The supernatant was transferred to new $1.5-\mathrm{mL}$ tubes with the addition of 2 volumes (or $400 \mu \mathrm{L}$ ) of chilled isopropanol followed by several but slow inversions of the tubes. In case of no visible precipitation, 1/10 volume of $3 \mathrm{M}$ sodium acetate (approximately $20 \mu \mathrm{L}$ ) was added to facilitate DNA precipitation. DNA was further precipitated at $-20^{\circ} \mathrm{C}$ for up to $1 \mathrm{~h}$. A volume of $200 \mu \mathrm{L} 70 \%$ ethanol was added onto the pellet with centrifugation at $5000 \mathrm{rpm}$ for $5 \mathrm{~min}$ at $4^{\circ} \mathrm{C}$. The supernatant was discarded, and the pellet dried and dissolved in TE (volume of TE depended on the visible quantity of pellet in the tube).

\section{Determination of genomic DNA quantity and purity}

DNA yield and purity were determined by two methods: agarose gel electrophoresis and spectrophotometric analyses. Aliquots $(1 \mu \mathrm{L})$ of DNA samples were run on a $0.8 \%$ agarose gel and compared with band intensities from known concentration of lambda DNA standards. The yield was further measured by checking the optical density (OD) in a UV spectrophotometer at $260 \mathrm{~nm}$. DNA purity was determined by calculating the absorbance ratio at $\mathrm{A}_{260 / 280^{\circ}}$.

\section{PCR-based amplification using extracted DNA samples}

PCR-based amplification of RAPD, SSR and SRAP fragments from extracted genomic DNAs was carried out; also restriction digestion, ligation and PCR amplification for AFLP were performed (data not shown). For RAPD, a PCR mixture of $20 \mu \mathrm{L}$ containing $25 \mathrm{ng}$ genomic DNA template, $0.3 \mathrm{U}$ Taq DNA polymerase (Bangalore Genei), $0.3 \mu \mathrm{M}$ primer, 2.5 $\mu \mathrm{L} 10 \mathrm{X} \mathrm{Taq}$ buffer, and $0.25 \mu \mathrm{L}$ dNTPs were subjected to PCR in a G-Storm thermal cycler as follows: an initial denaturation at $94^{\circ} \mathrm{C}$ for $5 \mathrm{~min}$, followed by 35 cycles of denaturation at $94^{\circ} \mathrm{C}$ for $1 \mathrm{~min}$, annealing at $37^{\circ} \mathrm{C}$ for $1 \mathrm{~min}$ and elongation at $72^{\circ} \mathrm{C}$ for $2 \mathrm{~min}$, and a final extension for $7 \mathrm{~min}$ at $72^{\circ} \mathrm{C}$.

For SSR, PCR was performed in a $20-\mu \mathrm{L}$ reaction volume containing 10X Taq buffer (10 $\mathrm{mM}$ Tris-HCl, $\mathrm{pH} 9.0,1.5 \mu \mathrm{M} \mathrm{MgCl}_{2}, 50 \mathrm{mM} \mathrm{KCl}, 0.01 \%$ gelatin), $0.2 \mathrm{mM}$ of each dNTP (Bangalore Genei), 0.1 U Taq DNA polymerase (Bangalore Genei) and $10 \mathrm{pM}$ each of forward and reverse primers. A total of $10 \mathrm{ng}$ genomic DNA was added as template in PCR tubes. An initial denaturation at $94^{\circ} \mathrm{C}$ for $3 \mathrm{~min}$ was followed by 35 cycles of denaturation at $94^{\circ} \mathrm{C}$ for $2 \mathrm{~min}$, annealing $\left(50^{\circ}\right.$ to $55^{\circ} \mathrm{C}$ ) and elongation at $72^{\circ} \mathrm{C}$ for $1 \mathrm{~min}$, and a final extension for $7 \mathrm{~min}$ at $72^{\circ} \mathrm{C}$. SRAP followed the protocol of Li and Quiros (2001).

\section{RESULTS AND DISCUSSION}

Agarose gel electrophoresis results showing band intensities of DNA isolated by our modified method in comparison with $1000 \mathrm{ng}$ lambda DNA are shown in Figure 1. The yield of DNA as revealed by UV-VIS spectrophotometric quantification and reading absorbance at $260 \mathrm{~nm}$, as well as DNA based on the $\mathrm{A}_{260} / \mathrm{A}_{280}$ ratio is presented in Table 1. Figures 2, 3 (A and B) and 4 show the results of downstream PCR-based reactions conducted with some of the DNA samples extracted using our method. Similar results (data not shown) have been obtained with this method for Cicer and Vigna. 


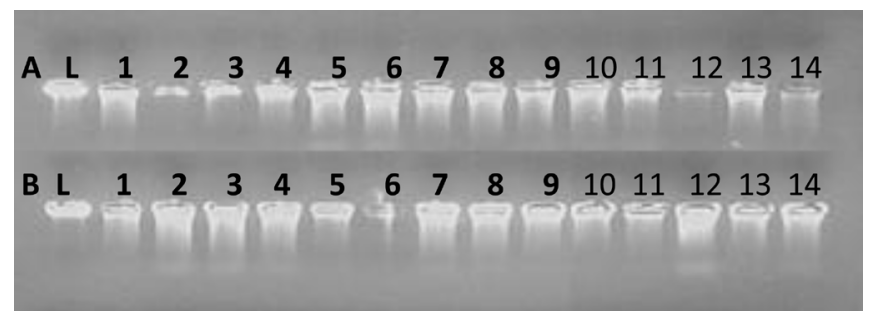

Figure 1. Electrophoresis of genomic DNA extracted from some Cajanus (cultivated and wild) species on $0.8 \%$ agarose gel. A. B. Lanes 1 to $14=1 \mu \mathrm{L}$ genomic DNA compared with $2 \mu \mathrm{L}(500 \mathrm{ng} / \mu \mathrm{L})$ lambda DNA ladder. Lanes $L=$ lambda DNA.

\begin{tabular}{|c|c|c|c|c|}
\hline \multirow[t]{2}{*}{ Genotype identity } & \multirow[t]{2}{*}{ Genotype name } & \multirow[t]{2}{*}{ Sample weight (mg) } & \multicolumn{2}{|c|}{ DNA concentration } \\
\hline & & & $\mathrm{ng} / \mu \mathrm{L}$ & $\lambda 260 / 280$ \\
\hline UPAS 120 & Cajanus cajan & 200 & 1188 & 1.83 \\
\hline Type 7 & C. cajan & 200 & 4776 & 1.90 \\
\hline ICP 8863 & C. cajan & 200 & 562 & 1.71 \\
\hline ICPL 87119 & C. cajan & 200 & 788 & 1.67 \\
\hline BDN 2 & C. cajan & 200 & 1456 & 1.69 \\
\hline BSMR 853 & C. cajan & 200 & 1506 & 1.64 \\
\hline MAL 13 & C. cajan & 200 & 832 & 1.72 \\
\hline PUSA 9 & C. cajan & 200 & 1163 & 1.69 \\
\hline DA 11 & C. cajan & 200 & 3739 & 1.94 \\
\hline NDA 1 & C. cajan & 200 & 1376 & 1.91 \\
\hline MA 6 & C. cajan & 200 & 969 & 1.86 \\
\hline MA 3 & C. cajan & 200 & 1360 & 1.91 \\
\hline GT 1 & C. cajan & 200 & 2541 & 1.82 \\
\hline PUSA 992 & C. cajan & 200 & 1201 & 1.90 \\
\hline Paras & C. cajan & 200 & 328 & 1.66 \\
\hline PUSA 33 & C. cajan & 200 & 483 & 1.90 \\
\hline ICPL 87 & C. cajan & 200 & 2086 & 1.95 \\
\hline GS 1 & C. cajan & 200 & 2476 & 1.95 \\
\hline Manak & C. cajan & 200 & 1319 & 1.93 \\
\hline GT 100 & C. cajan & 200 & 1735 & 1.96 \\
\hline Bahar & C. cajan & 200 & 786 & 1.83 \\
\hline IPA-8F & C. cajan & 200 & 1412 & 1.91 \\
\hline IPA-15F & C. cajan & 200 & 801 & 1.80 \\
\hline IPA-16F & C. cajan & 200 & 1249 & 1.85 \\
\hline IPA-70 & C. cajan & 200 & 2056 & 1.94 \\
\hline ICP-7626 & C. cajan & 200 & 955 & 1.82 \\
\hline ICP-8840 & C. cajan & 200 & 539 & 1.90 \\
\hline IPA-69 & C. cajan & 200 & 2237 & 1.76 \\
\hline ICP-10958 & C. cajan & 200 & 496 & 1.81 \\
\hline ICPL-20102 & C. cajan & 200 & 963 & 1.89 \\
\hline ICPL-20107 & C. cajan & 200 & 892 & 1.83 \\
\hline ICPL-20116 & C. cajan & 200 & 1155 & 1.84 \\
\hline ICPL-20125 & C. cajan & 200 & 962 & 1.83 \\
\hline ICPL-20135 & C. cajan & 200 & 1245 & 1.94 \\
\hline ICP-1629-1 & C. cajanifolious & 200 & 816 & 1.82 \\
\hline ICP-1629-2 & C. cajanifolious & 200 & 913 & 1.84 \\
\hline ICP-15685 & C. scarabaeoides & 200 & 458 & 1.67 \\
\hline ICP-15724 & C. scarabaeoides & 200 & 919 & 1.81 \\
\hline ICP-15697 & C. scarabaeoides & 200 & 700 & 1.72 \\
\hline ICP-15661 & C. platypcarpus & 200 & 798 & 1.50 \\
\hline ICP-15666 & C. platypcarpus & 200 & 1888 & 1.87 \\
\hline ICP- 15760 & C. sericeus & 200 & 3470 & 2.10 \\
\hline ICP-15761 & C. sericeus & 200 & 3608 & 1.98 \\
\hline ICP- 15624 & C. albicans & 200 & 446 & 1.70 \\
\hline ICP- 15622 & C. albicans & 200 & 4015 & 2.20 \\
\hline Total & - & - & 65.663 & 82.70 \\
\hline Average & - & - & 1459.17 & 1.84 \\
\hline
\end{tabular}




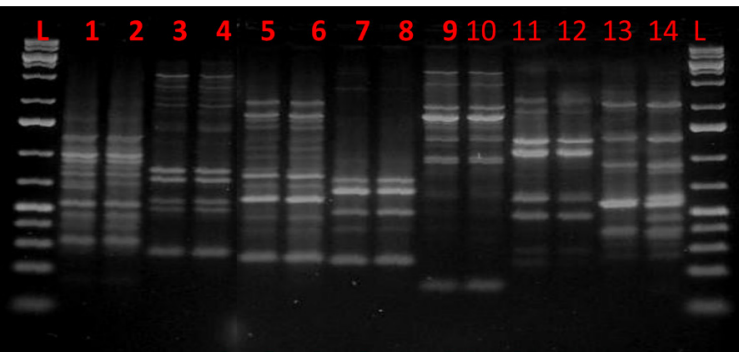

Figure 2. Electrophoresis of genomic DNA extracted from some Cajanus (cultivated and wild) species on $1.5 \%$ agarose gel after PCR with random amplified polymorphic DNA (RAPD) markers. Lanes $L=100$-bp ladder; lanes 1 to $14=$ RAPD profiles from Cajanus species.

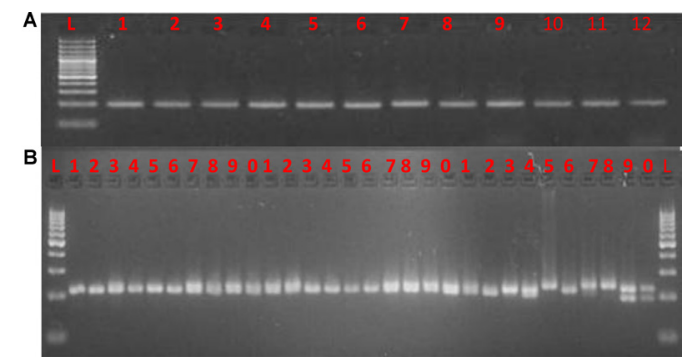

Figure 3. Electrophoresis of genomic DNA extracted from some Cajanus (cultivated and wild) species on 3\% agarose gel after PCR with monomorphic (A) and polymorphic (B) microsatellite markers. Lanes $L=100$-bp ladder. A. Lanes 1 to 12 = profiles from a monomorphic SSR marker. B. Lanes show profiles of a polymorphic SSR marker on 30 genotypes of Cajanus.

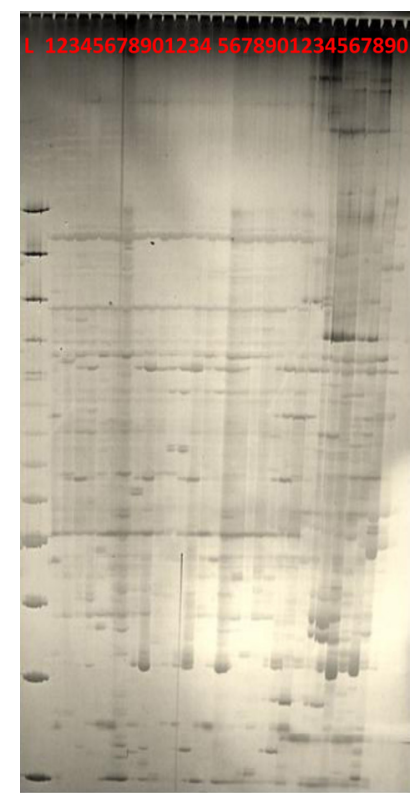

Figure 4. Sequence-related amplified polymorphism (SRAP) of genomic DNA extracted from some Cajanus (cultivated and wild) species on $6 \%$ acrylamide gel. Lane $L=100$-bp ladder; other lanes show SRAP band pattern of 30 different Cajanus species. 
The DNA yield obtained using this modified method ranged from 10 to $40 \mu \mathrm{L}$ per $200 \mathrm{mg}$ of leaf sample. When estimated, the aforementioned yield produced a high-molecular weight DNA range of 328 to $4776 \mathrm{ng} / \mu \mathrm{L}$, with an average of $1459.17 \mathrm{ng} / \mu \mathrm{L}$, for the 45 samples of Cajanus, as shown in Table 1. The $\mathrm{A}_{260} / \mathrm{A}_{280}$ ratio was in the range of 1.66 to 2.20 , with an average of 1.84, indicating insignificant/low levels of protein and polysaccharide contamination (Burden and Whitney, 1995). RNase treatment was performed, which ensured removal of RNA and extraneous nucleic acids. As stated earlier, this method unlike some recently reported high-quality plant DNA extraction methods (Aljanabi and Martinez, 1997; Zhang and Stewart, 2000; Karakousis and Langridge, 2003; Manen et al., 2005; Bokszczanin and Przybyla, 2006; Chakraborti et al., 2006; Arbi et al., 2009; Biswas and Biswas, 2011), utilizes neither liquid nitrogen, lyophilization (freeze-drying), alternating cold (about $-80^{\circ} \mathrm{C}$ ) nor enzymatic digestion for grinding and/or rupturing of the cell and nuclear walls. For a properly planned study, one person is able to process as many as 200 samples in a 5-day working period with a labor cost as low as 100 to US\$110 or between 1.8 and US\$2 per leaf sample. All the extraction procedures were carried out in 1.5- and 2-mL tubes, which is cost saving as well as providing ease of experimental handling with laboratory wares.

Downstream PCR-based reaction results, presented in Figures 2 (RAPD), 3 (SSR) and 4 (SRAP), showed that the DNA extracted using this method is stable, of good quality and purity, and suitable for diverse molecular studies. Bands obtained for each marker system were clearly visible and, where necessary, discriminatory enough to show the relevance of that marker system in unraveling intrinsic genome complexity and diversity. Although other aforementioned rapid DNA extraction protocols using liquid nitrogen, sophisticated grinding machines such as the GenoGrinder or enzymatic digestion could result in 1000 to 2000 or more samples within the same period, it is important to note that most projects within Africa and Asia are supported by government and/or international funding agencies with a 3- to 5-year timeline. Thus, extraction of 1000 to 2000 DNA samples in a day or week is hardly required; however, a means of cost saving but ensuring the extraction of good-quality DNA is required.

We conclude that this modified DNA extraction method, which has been extensively used for Cajanus, Cicer and Vigna, can be applied for the extraction of DNA of high quality and yield from most plant species, especially members of the Leguminosae. It is suitable for developing countries in Africa and Asia, where funds and enabling environment for highthroughput DNA extraction may be limiting.

\section{ACKNOWLEDGMENTS}

Research supported by the Department of Biotechnology, India, and the Third World Academy of Science, Trieste, Italy (DBT-TWAS Postdoctoral Fellowship in Plant Biotechnology/Genomics in 2010).

\section{REFERENCES}

Aljanabi SM and Martinez I (1997). Universal and rapid salt-extraction of high quality genomic DNA for PCR-based techniques. Nucleic Acids Res. 25: 4692-4693.

Arbi G, Naceur B, Chokri M, Mohamed B, et al. (2009). A simple, rapid and efficient method for the extraction of genomic DNA from Allium roseum L. (Alliaceae). Afr. J. Biotechnol. 8: 4020-4024.

Attitalla IH (2011). Modified CTAB method for high quality genomic DNA extraction from medicinal plants. Pak. J. Biol. Sci. 14: 998-999. 
Biswas K and Biswas R (2011). A modified method to isolate genomic DNA from plants without liquid nitrogen. Curr. Sci. 100: 1622-1624.

Bokszczanin K and Przybyla AA (2006). Copper (II) acetate improves the quality of pear (Pyrus) DNA during extraction. Plant Mol. Biol. Rep. 24: 249a-249d.

Burden DW and Whitney DB (1995). Biotechnology, Proteins to PCR: A Course in Strategies and Lab Techniques. Birkhauser, Boston.

Chakraborti D, Sarkar A, Gupta S and Das S (2006). Small and large scale genomic DNA isolation protocol for chickpea (Cicer arietinum L.), suitable for molecular marker and transgenic analyses. Afr. J. Biotechnol. 5: 585-589.

Chandra A and Saxena R (2007). A rapid protocol for isolating genomic DNA from tropical grass species suitable for RAPD, ISSR and STS. Cytologia 72: 427-434.

Dehestani A and Kazemi-Tabar SK (2007). A rapid efficient method for DNA isolation from plants with high levels of secondary metabolites. Asian J. Plant Sci. 6: 977-981.

Gupta AK, Harish, Rai MK, Phulwaria M, et al. (2011). Isolation of genomic DNA suitable for community analysis from mature trees adapted to arid environment. Gene 487: 156-159.

Gurudeeban S, Ramanathan T, Satyavani K and Dhinesh T (2011). Standardization of DNA isolation and PCR protocol for RAPD analysis of Suaeda sp. Asian J. Biotechnol. 3: 486-492.

Japelaghi RH, Haddad R and Garoosi GA (2011). Rapid and efficient isolation of high quality nucleic acids from plant tissues rich in polyphenols and polysaccharides. Mol. Biotechnol. 49: 129-137.

Karakousis A and Langridge P (2003). A high-throughput plant DNA extraction method for marker analysis. Plant Mol. Biol. Rep. 21: 95a-95f.

Li G and Quiros CF (2001). Sequence-related amplified polymorphism (SRAP), a new marker system based on a simple PCR reaction: its application to mapping and gene tagging in Brassica. Theor. Appl. Genet. 103: 455-461.

Manen JF, Sinitsyna O, Aeschbach L, Markov AV, et al. (2005). A fully automatable enzymatic method for DNA extraction from plant tissues. BMC Plant Biol. 5: 23.

Okpodu CM and Abdullah-Israel M (2011). A DNA isolation protocol suitable for RAPD analysis from fresh or herbariumstored leaves of a historic Quercus virginiana L. J. Plant Sci. 6: 77-87.

Sahasrabudhe A and Deodhar M (2010). Standardization of DNA extraction and optimization of RAPD-PCR conditions in Garcinia indica. Int. J. Botonay 6: 293-298.

Sharma R, Kumar V, Mohapatra T, Khandelwal V, et al. (2012). A simple and non-destructive method of direct-PCR for plant systems. J. Plant Biol. 55: 114-122.

Tiwari KL, Jadhav SK and Gupta S (2012). Modified CTAB Technique for isolation of DNA from some medicinal plants. Res. J. Med. Plant 6: 65-73.

Xu X, Kawasaki S, Fujimura T and Wang C (2005). A protocol for high-throughput extraction of DNA from rice leaves. Plant Mol. Biol. Rep. 23: 291-295.

Zhang J and Stewart JM (2000). Economical and rapid method for extracting cotton genomic DNA. J. Cotton Sci. 4: 193-201. 